Journal of Nepal Geological Society, 2013, Vol. 46, pp. 199-210

\title{
Physical, mechanical and petrographic properties of Lesser Himalayan rocks from Kavre area: An assessment of quality for concrete aggregate
}

\author{
*Prem Nath Paudel and Naresh Kazi Tamrakar \\ Central Department of Geology, Tribhuvan University, Kirtipur, Kathmandu, Nepal \\ (*Email: sriprem.geo@gmail.com)
}

\begin{abstract}
With rapidly growing population, development of human civilization and increasing construction of infrastructures, the demand of aggregate is increasing day by day. The quarries of naturally occurring sand and gravel are not sufficient to fulfill the demand, and are disturbing the river environments. Therefore, the crushed-rock aggregates should be used to meet the requirements. The accessible resources, quality and quantity for aggregates play an important role in the durability of roads, buildings, projects, many other infrastructures and sustainable development. Negligence of quality of aggregates would lead to rapid degradation of concrete structures. Therefore, being aware of these things, quality of aggregates should be prioritized. The exploration of outcrops from which suitable aggregates can be exploited is essential. This study aims to explore and evaluate the resources and quality of crushed-rock aggregates from the Lesser Himalayan rocks in the Kavre area.
\end{abstract}

Different kinds of rocks were identified from the outcrop in the study area: quartzite, psammitic schist, calcquartzite, metasandstone and metasiltstone. Thirteen representative samples were taken from different lithological formations. The water absorption value (WAV) of samples ranges from 0.302 to $2.393 \%$. Dry density varies from 2.308 to $2.743 \mathrm{gm} / \mathrm{cm} 3$ and the uniaxial compressive strength value ranges from 23.62 to $217.92 \mathrm{MPa}$. In general, these values indicate that the aggregates are compact and strong. The aggregate crushing value (ACV) ranges from 19.56 to $35.4 \%$ and the aggregate impact value (AIV) ranges from 11.02 to $23.84 \%$ showing that the aggregates are resistant against compressive load and strong against impact load. The sodium sulphate soundness value (SSSV) lies between 5.95 to $16.66 \%$ and methylene blue absorption values (MBAV) in all samples are $<1 \%$ indicating that the samples are durable and chemically sound. The alkali silica reactive features, swelling and expanding clay minerals like chert, opal, high-quartz, extremely deformed fractured quartz, smectite, and kaolinite are absent. Though some quartz grains are undulosed and fractured, they are mega and low-quartz. Only the clay mineral illite, $1 \mathrm{M}$ type is present in very small proportion. All these parameters show that the samples of the Lesser Himalayan rocks from the Kavre area are suitable and acceptable for concrete aggregates of general.

Key words: Lesser Himalaya, aggregates, rock mass rating, aggregate crushing value, sodium sulphate soundness value, petrography

Received: 18 April, 2013

Revision accepted: 31 June, 2013

\section{INTRODUCTION}

Infrastructures in the country are increasing day by day due to rapid growth of population. The demand of construction material has also increased. Rocks and sediments are main sources of construction materials, which are used as paving floors, roofing, concrete aggregate and road aggregate. Quality of aggregates used in concrete structures is of great concerns. Several lab tests and analyses are made to characterize the physical, mechanical, chemical and petrographic properties of these aggregates. Unfortunately, there is a growing practice of infrastructure construction without following the specification or the standard of materials used. The quality of aggregates should be kept at high priority. As naturally occurring sand and gravel are not sufficient to fulfill the demand in the city, and river quarrying is disturbing the river environment, crushed-stone aggregates should be used to meet the requirements. Most of the crushed-stone (aggregate) is supplied from Kavre area in Kathmandu and Banepa valley. The Precambrian to Paleozoic rocks of the Kathmandu Complex (Stöcklin 1980) are the major sources of aggregate in Kavre, Dhading, Makawanpur and many other parts of 
the country. The high potential areas for concrete aggregate are mainly located along the BP Highway, Araniko Highway and surrounding area in Kavre area. The location of the study area is shown in Fig. 1. The best selection of rocks for aggregate depends on properties and set by national and international specifications. The widely accepted standards are American standard of testing materials (ASTM) and British standard (BS). The Indian standard (IS) is also accepted in Nepal. Department of Road (DOR) Nepal (2001) published standard specification for road, bridge and pavement structures. Tamrakar et al. (2002), Maharjan and Tamrakar (2003), Dhakal et al. (2006), Khanal and Tamrakar (2009), and Tamrakar and Paudel (2011) analysed various rocks for concrete, road and pavement aggregates.

\section{METHODOLOGY}

The 1:25000 scale topographic maps was used for geological mapping. Various rock types were mapped along with their attitudes and descriptions. Samples for microscopic study and laboratory testing were also collected. The engineering geological study of the rock outcrops, the lithological characteristics, rock mass properties, weathering grade, and indurations were studied during the fieldwork. The rock outcrops were classified according to the rock mass rating (RMR) system (Bieniawski 1989). The representative samples of different rock types from different lithological formations having 8 to $10 \mathrm{Kg}$ per station were collected for the laboratory study. This study discusses the tests of

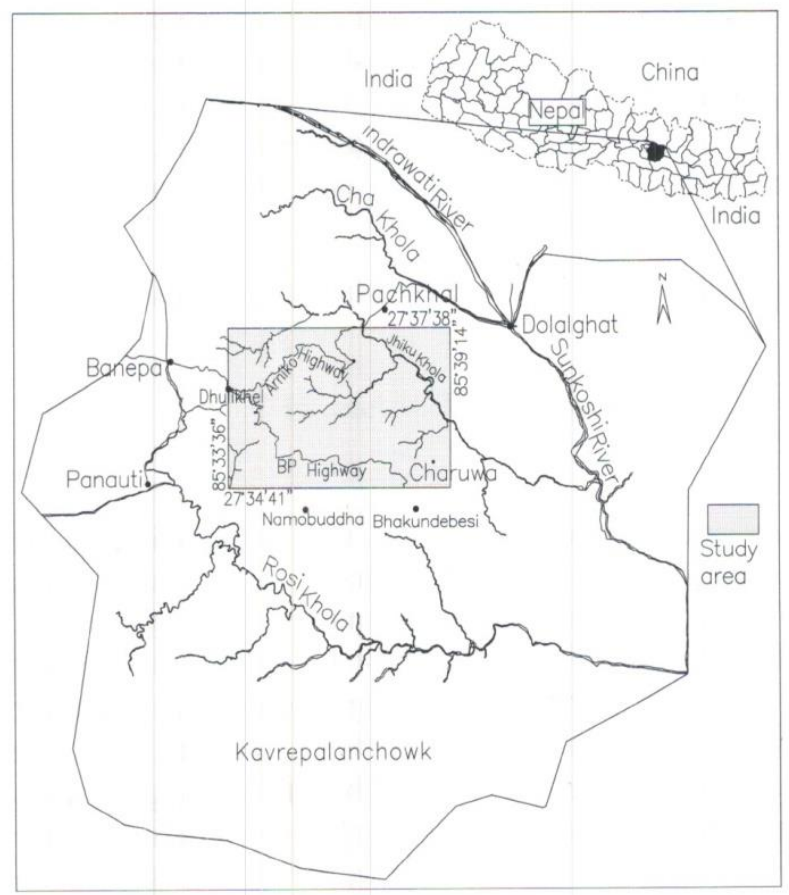

Fig. 1: Location map of the study area. crushed rock aggregates by some physical, mechanical, chemical and petrographic parameters.

From the block of samples two sets of cores of diameter $2.51 \mathrm{~cm}$ and $4.5 \mathrm{~cm}$ long were drilled out in the laboratory. One set sample was used for testing point-load strength index and another set of core sample was used to determine the water absorption and dry density. The water absorption value was determined by measuring the increase in sample weight owing to pore-water according to Caliper and saturation method (ISRM 1979). The samples were prepared for mechanical test using hammer, sieves of size $25 \mathrm{~mm}$ and $20 \mathrm{~mm}$ for aggregate crushing value (ACV) and 12.5 $\mathrm{mm}$ and $10 \mathrm{~mm}$ sieve for Aggregate Impact Value (AIV). The tests for durability against weathering and assessment of clay minerals were also made. The sodium sulphate soundness test was done following ASTM Designation C88-05 (ASTM 2005). The methylene blue absorption test was used to test soundness of aggregates by determining existence of swelling clays like smectite according to Hills and Pttifer (1985).

Thirteen thin sections were examined for the petrographic properties of aggregate, alkali-silica reactivity analysis considering ASTM Designation C295-03 (ASTM, 2003). Samples having Very fine-grained $(<15 \mu \mathrm{m})$ quartz and visible clay matrix were selected for the XRD analysis after examining in the petrographic microscope. The reactive silica and harmful clay minerals present in the aggregate were studied by means of X-ray diffractometry. The air dried samples were used in XRD analysis (Bruker's D8 advance diffractometer, computer controlled). The scan range for bulk mineralogy were $2-402 \theta$ at a speed of $2 \%$ min and 20-22 $2 \theta$ at a speed of $0.5 \% \mathrm{~min}$ for detection of silica and 4-14 $2 \theta$ at a speed of $0.5 \% \mathrm{~min}$ for the detection of clay minerals. The peaks of diffractograms obtained from scanning silica and clay were compared with the curves of opal, chalcedony, tridymite, micro-quartz, crystobalite, illite, smectite, kaolinite and chlorite to analyse their presence in the samples.

\section{GEOLOGICAL SETTING}

The rocks of the Kavre area can be assigned in to the Kathmandu Complex and the Nawakot Complex. These two Complexes are distinctly separated by the Chak-Roshi Thrust which is a part of the Mahabharat Thrust (Stöcklin and Bhattarai 1977; Stöcklin 1980). Tamrakar et al. (1997) prepared a geological map of the Jhiku Khola watershed area, and generalized lithostrtigraphic column of the Lesser Himalayan rocks in the Kavre area. Paudel and Tamrakar (2012) studied the geology and rock mass characteristics of the Dhulikhel-Panchkhal area. The stratigraphic subdivision of the area is given in Table 1 and the geological map of the study area is shown in Fig. 2. 
Table 1: Stratigraphic sub-divisions of the Kavre area, central Nepal Lesser Himalaya (based on Stöcklin 1980).

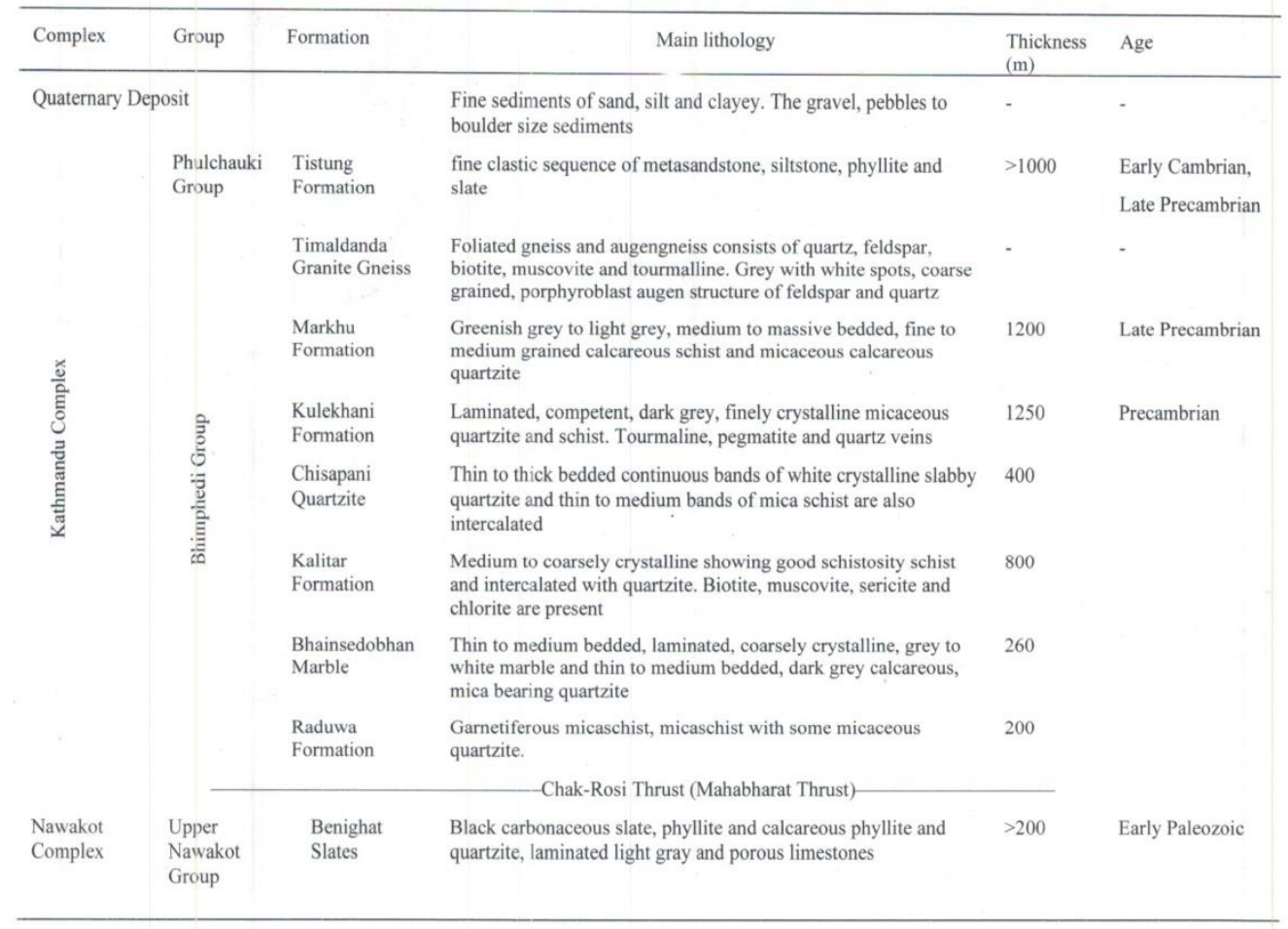

Mainly the Bhimphedi group and the lower unit of the Phulchoki group (i.e., Tistung Formation) of the Kathmandu Complex are distributed in the study area. Small part of the upper unit of the Upper Nawakot Group (i.e., Benighat Slate) is also exposed in the footwall of the Chak-Rosi Thrust at the NE of the study area. The essential lithological differences between the Kathmandu and the Nawakot Complexes are the metamorphic grade. The Kathmandu Complex consists of relatively high-grade metamorphic rocks such as garnetiferous mica schist, micaceous quartzite and calcareous schist. The Timaldanda Granite Gneiss is intruded within the Bhimphedi Group at the SE part of the study area. The unmetamorphosed or weakly metamorphosed rocks of the Tistung Formation of the Phulchouki Group are well exposed at the western part of the study area. The valley filling soft sediment is also widely distributed in the present study area. The major attitudes of strata extend NW-SE and dip SW.

\section{ROCK MASS CHARACTERISTICS}

\section{Discontinuity characteristics}

The rock mass characteristics were measured at thirteen locations of different lithological formations. Three major joint sets with parallel to bedding plane were found. Most of the bedding joints are dipping towards southwest. The other major joint sets are oblique to perpendicular with bedding joints at almost all locations. Most of the bedding and foliations contain close to moderate $(6-60 \mathrm{~cm})$ spacing. These types of spacing distribute the rock mass into number of blocks. Almost all the persistency of beddings are high to very high $(10 \mathrm{~m}$ to $>20 \mathrm{~m})$. It defines low stability of rock mass that becomes easy to excavate. The presence of more joints and fractures is favourable for aggregate excavation.

Discontinuity surfaces are smooth to rough. Bedding and foliation roughness is relatively slightly smooth than other joint planes. The joint apertures are moderate open to wide $(0.1 \mathrm{~mm}$ to $1 \mathrm{~cm})$. The most of the infill materials are clay, silt with organic matters and vegetation. The weathering grade of rocks was classified according to weathering classification (GSL, 1977). Most of the rocks on the outer surface are faintly weathered to slightly weathered. Rocks are weakly indurated to strongly indurated according to the criteria of Larson et al. (1995).

\section{Rock mass classification}

The rock mass in the study area are classified into fair rock and good rock class according to the RMR system (Bieniawski 1989) shown in Table 2. The rock masses at the locations KV9, KV3, KV13, KV11 and KV12 are fair rocks and at the location $\mathrm{KV} 8, \mathrm{KV} 7, \mathrm{KV} 6, \mathrm{KV} 10, \mathrm{KV} 5$, 


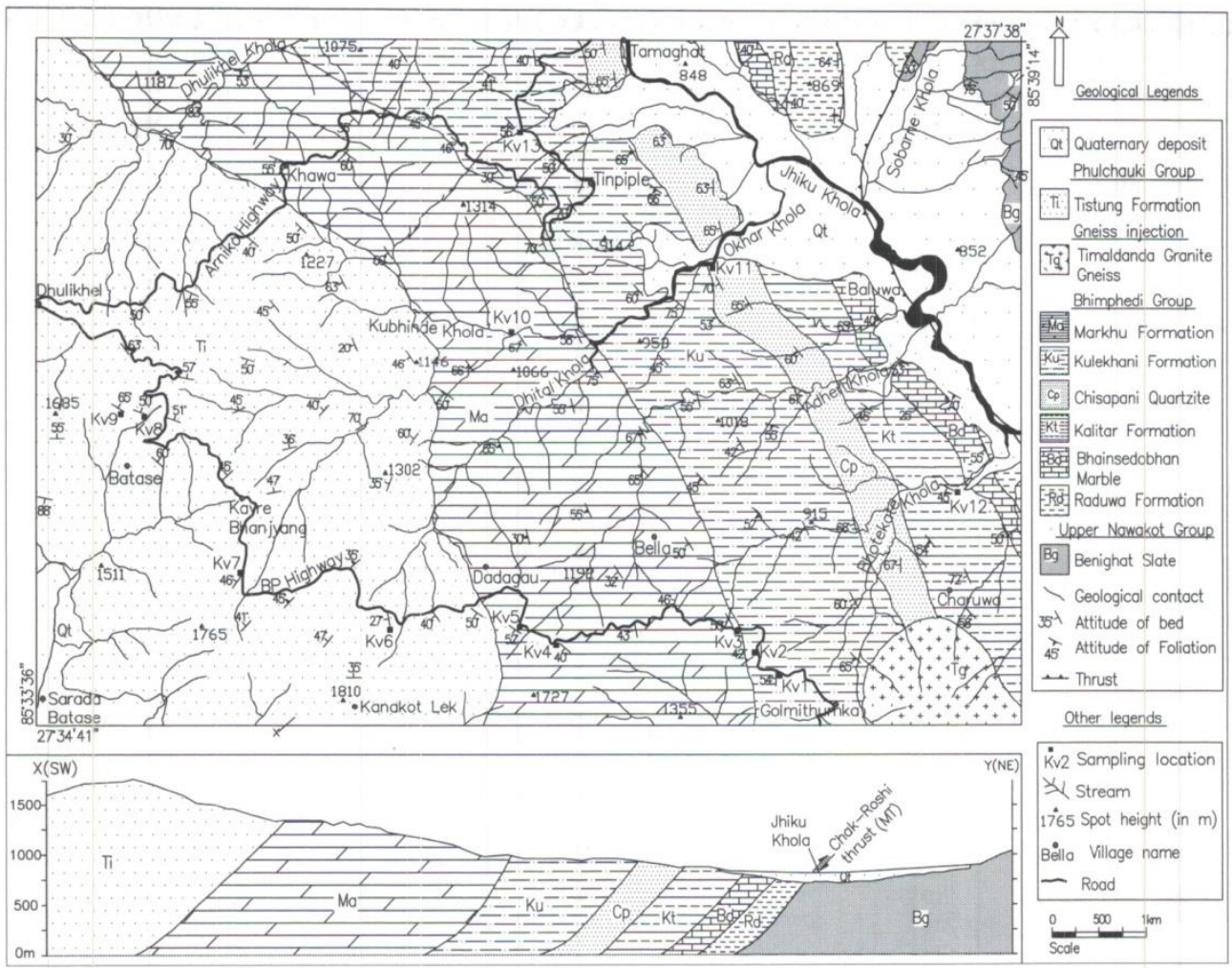

Fig. 2: Geological map of the Kavre area, central Nepal Lesser Himalaya (Compiled after Tamrakar et al. 1997).

KV4 and KV2 are good rocks. The RMR values for the meta-siltstone (KV9) and micaceous white quartzite of the Kalitar Formation are minimum. Due to the effect of the ground water condition, low spacing and rock quality designation (RQD) rating ( $\mathrm{JV}$ is greater), the RMR at KV12 is minimum. Although the effect of ground water condition, all the parameters are strong for the calcareous quartzite at the location KV10, the RMR value is maximum.

\section{PROPERTIES OF AGGREGATES}

The physical properties of aggregates are those that refer to the physical structures of the particles that make up the aggregate. The strength, elasticity and abrasion are performed by the mechanical properties. The soundness workability and durability of aggregates can be determined by some chemical tests. The compositional constituents, alkali-silica reactivity and impurities are also the important parameters. Among them some properties were studied separately with their standard consideration (Table 3 ).

\section{Physical properties}

The measured WAV ranges from 0.302 to $2.392 \%$. The data show that the rocks are compact enough with negligible pores, and are suitable for aggregate (ASTM 1989). Strong aggregates have a very low WAV $(<1 \%)$. The WAV above $4 \%$ needs further test on the aggregate to determine its acceptability. The calculated dry density ranges from 2.308 to $2.743 \mathrm{gm} / \mathrm{cm}^{3}$, and rocks. The dry density of aggregates normally used in construction is $2-3 \mathrm{gm} / \mathrm{cm}^{3}$ and average value of about $2.6 \mathrm{gm} / \mathrm{cm}^{3}$ is in road construction (ASTM 1994).

\section{Mechanical properties}

The calculated ACV ranges from $19.56 \%$ to $35.4 \%$. The ACV up to $30 \%$ is mechanically sound for road aggregate and up to $45 \%$ is satisfactory for use in other concrete aggregate (NS 1994). The rock samples KV3 and KV9 are weak to resist crushing. The others are stronger and mechanically sound. The result of AIV ranges from 11.02 to $23.84 \%$. The AIV lying between 10 and $20 \%$ is considered strong (NS 1994). The AIV between 20 and $30 \%$ is satisfactory. Therefore, both ACV and AIV agree with the standard values and indicate that some rocks are strong (KV8, KV7, KV6, KV10, KV5, KV4 and KV1) and some are satisfactory (KV9, KV3, KV13, KV2, KV11 and KV12) to resist impact.

\section{Chemical properties}

The sound aggregates are generally durable. Five soaking 
Physical, mechanical and petrographic properties of Lesser Himalayan rocks

Table 2: Determination of weathering grade, induration, uniaxial compressive strength and rock mass classification.

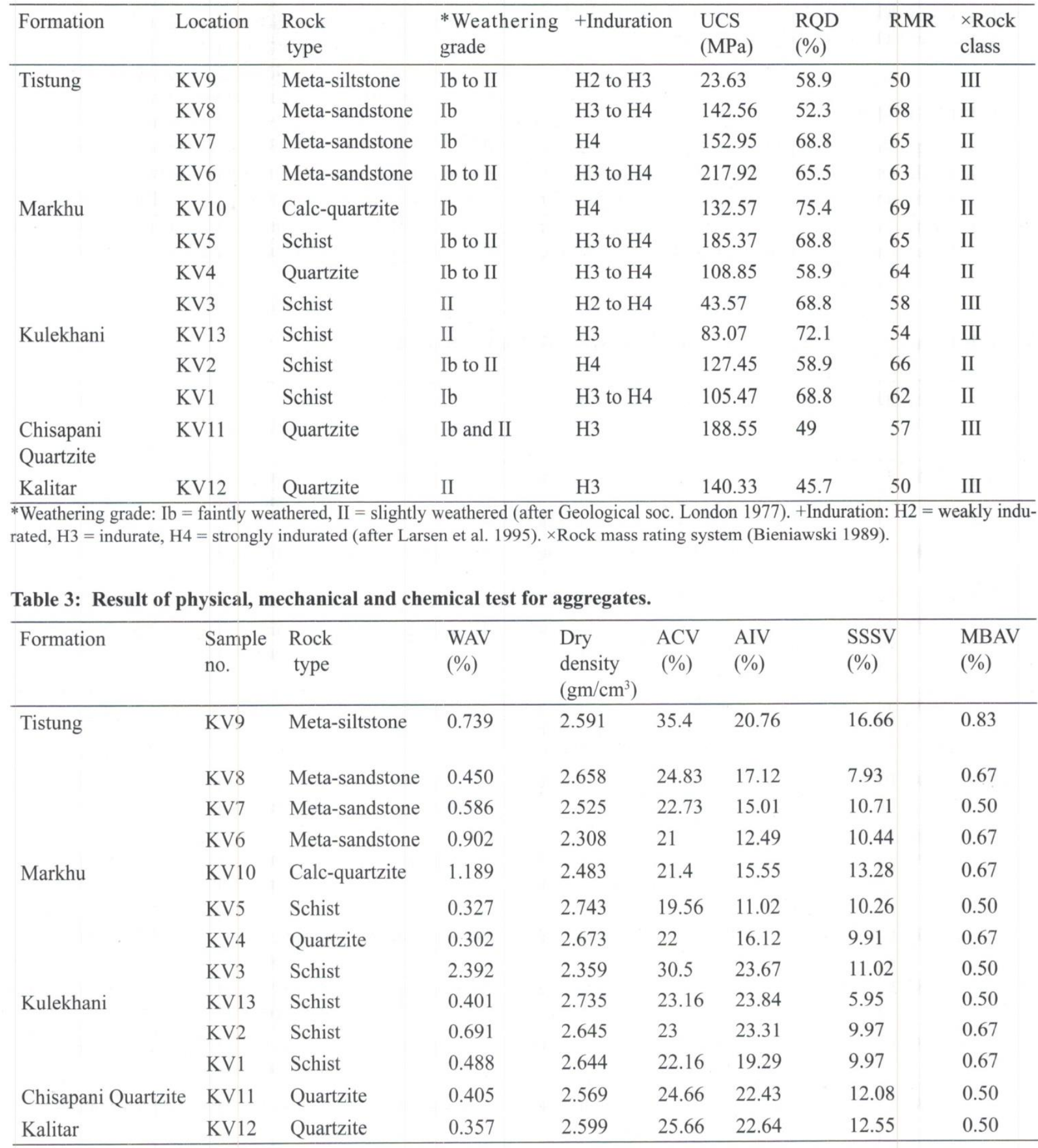

and drying cycles were carried out in sodium sulphate soundness test. The result of sodium sulphate soundness value (SSSV) varies from 5.95 to $16.66 \%$. The value below the $12 \%$ is chemically sound (ASTM C $88-05$; NS 1994). The metasiltstone of the Tistung Formation (KV9), quartzite of the Markhu. Formation (KV10), micaceous quartzite of Chisapani Quartzite (KV11) and quartzite of Kalitar Formation (KV12) are chemically fair as they possess SSSV $>12 \%$. Other samples being durable, show their resistance to frost weathering. The methylene blue absorption value 
(MBAV) in all samples is less than $1 \%$. It shows that the swelling clay minerals and organic matters are negligible, and aggregates from these rocks can perform well.

\section{Petrographic properties}

The petrographic studies gave the relative amount of the constituents, their physical and mineralogical characteristics. Some selected samples were analysed further in XRD after they were examined under a polarizing microscope. The results of textural and compositional analyses of samples are given in Table 4 and Table 5, respectively.

Quartz grains are predominant (52 to $81 \%$ ) in the sample no. KV4, KV6, KV7, KV8, KV9, KV11 and KV12. Feldspar grains are very less $(<7 \%)$ in proportion in all samples. Mica (biotite and muscovite) grains are greater or nearly equal with quartz grains in sample no. KV5, KV1, $\mathrm{KV} 2, \mathrm{KV} 3, \mathrm{KV} 5$ and KV13. Due to the high mica in these samples, rocks tend to split along foliation. The chlorite in metasandstone and in schist are very less in proportion $(<5 \%)$. Some calcite grains are seen in sample KV3 and KV10. The other minerals include heavy minerals, opaque

Table 4: Textural and microstructural studies of samples from thin section.

\begin{tabular}{|c|c|c|c|c|c|c|c|}
\hline \multirow[t]{2}{*}{ Formation } & \multirow{2}{*}{$\begin{array}{l}\text { Sample } \\
\text { no. }\end{array}$} & \multirow{2}{*}{$\begin{array}{l}\text { Mean } \\
\text { grain size } \\
(\mu \mathrm{m})\end{array}$} & \multirow[t]{2}{*}{ Grain shape } & \multirow[t]{2}{*}{ Texture } & \multicolumn{2}{|r|}{ Fabric } & \multirow[t]{2}{*}{ Deformation } \\
\hline & & & & & Homogenity & Microfabric & \\
\hline \multirow[t]{4}{*}{ Tistung } & KV9 & 47 & $\begin{array}{l}\text { Subangular, } \\
\text { subhedral, elon- } \\
\text { gated mica }\end{array}$ & $\begin{array}{l}\text { Moderately } \\
\text { sorted, } \\
\text { submature }\end{array}$ & Homogeneous & $\begin{array}{l}\text { Microlaminae, floating } \\
\text {, point and tangential } \\
\text { contact }\end{array}$ & $\begin{array}{l}\text { Slightly } \\
\text { deformed, } 1 \text { set } \\
\text { foliation }\end{array}$ \\
\hline & KV8 & 71 & $\begin{array}{l}\text { Rounded to an- } \\
\text { gular, elongated } \\
\text { mica }\end{array}$ & $\begin{array}{l}\text { Moderately } \\
\text { sorted, relict }\end{array}$ & Homogeneous & $\begin{array}{l}\text { Microlaminae, tangen- } \\
\text { tial contact }\end{array}$ & $\begin{array}{l}\text { Slightly } \\
\text { deformed, } 1 \text { set } \\
\text { foliation }\end{array}$ \\
\hline & KV7 & 73 & $\begin{array}{l}\text { Subangular- } \\
\text { rounded, elon- } \\
\text { gated mica }\end{array}$ & $\begin{array}{l}\text { Moderately } \\
\text { sorted }\end{array}$ & Homogeneous & $\begin{array}{l}\text { Microlaminae, tangen- } \\
\text { tial to concavo-convex } \\
\text { contact }\end{array}$ & $\begin{array}{l}\text { Slightly de- } \\
\text { formed }\end{array}$ \\
\hline & KV6 & 98 & $\begin{array}{l}\text { Anhedral - } \\
\text { subhedal }\end{array}$ & $\begin{array}{l}\text { Moderately } \\
\text { sorted, ma- } \\
\text { ture, relict }\end{array}$ & Heterogeneous & $\begin{array}{l}\text { Massive, point to suture } \\
\text { contact }\end{array}$ & $\begin{array}{l}\text { Slightly } \\
\text { deformed, } 1 \text { set } \\
\text { foliation }\end{array}$ \\
\hline \multirow[t]{4}{*}{ Markhu } & KV10 & 81 & $\begin{array}{l}\text { Subhedral - } \\
\text { anhedral, an- } \\
\text { gular }\end{array}$ & Granoblastic & $\begin{array}{l}\text { Heterogeneous, } \\
\text { patches }\end{array}$ & $\begin{array}{l}\text { Massive, polycrystal- } \\
\text { line, tangential contact }\end{array}$ & 1 set foliation \\
\hline & KV5 & 69 & $\begin{array}{l}\text { Anhedral, } \\
\text { elongated mica }\end{array}$ & $\begin{array}{l}\text { Lepidoblas- } \\
\text { tic, crenu- } \\
\text { lated }\end{array}$ & Heterogeneous & $\begin{array}{l}\text { Mica fish, polycrystal- } \\
\text { line, microlaminnae }\end{array}$ & 2 set foliation \\
\hline & KV4 & 101 & Anhedral & Granoblastic & Homogeneous & $\begin{array}{l}\text { Massive, } \\
\text { suture contact }\end{array}$ & 1 set foliation \\
\hline & KV3 & 94 & Anhedral & Granoblastic & Heterogeneous & $\begin{array}{l}\text { Massive, indented- } \\
\text { sutured contact }\end{array}$ & 1 set foliation \\
\hline \multirow[t]{3}{*}{ Kulekhani } & KV13 & 242 & $\begin{array}{l}\text { Anhedral, elon- } \\
\text { gated }\end{array}$ & Porphyritic, & Heterogeneous & $\begin{array}{l}\text { Massive, mica fish, } \\
\text { sutured contact }\end{array}$ & 2 set foliation \\
\hline & KV2 & 99 & Anhedral & Granoblastic & Heterogeneous & $\begin{array}{l}\text { Massive, polycrystanl- } \\
\text { line }\end{array}$ & 2 set foliation \\
\hline & KV1 & 106 & $\begin{array}{l}\text { Anhedral, elon- } \\
\text { gated }\end{array}$ & $\begin{array}{l}\text { Lepidoblas- } \\
\text { tic crenulated }\end{array}$ & Heterogeneous & $\begin{array}{l}\text { Tangential to suture } \\
\text { contact, microlaminae }\end{array}$ & 2 set foliation \\
\hline $\begin{array}{l}\text { Chisapani } \\
\text { Quartzite }\end{array}$ & KV11 & 330 & Anhedral & Porphyritic & Heterogeneous & $\begin{array}{l}\text { Massive, sutured } \\
\text { contact }\end{array}$ & 1set foliation \\
\hline Kalitar & KV12 & 272 & Anhedral & Porphyritic & Heterogeneous & $\begin{array}{l}\text { Massive, suture, tan- } \\
\text { gential contact }\end{array}$ & 1set foliation \\
\hline
\end{tabular}


Table 5: Compositional analysis of rock samples obtained from thin section studies.

\begin{tabular}{lllllllllll}
\hline \multirow{2}{*}{$\begin{array}{l}\text { Sample } \\
\text { no. }\end{array}$} & Quartz & Feldspar & Biotite & Muscovite & Sericite & Calcite & Chlorite & Other & $*$ Ipw & Description \\
\hline KV9 & 58 & 4 & - & 17 & 8 & - & 3 & 9 & 0.11 & Metasiltstone \\
KV8 & 62 & 6 & - & 16 & 7 & - & 3 & 9 & 0.09 & Metasandstone \\
KV7 & 60 & 7 & - & 15 & 8 & - & 5 & 5 & 0.09 & Metasandstone \\
KV6 & 59 & 3 & 13 & 12 & 3 & - & 3 & 5 & 0.11 & Metasandstone \\
KV10 & 44 & 3 & 34 & 9 & - & 5 & - & 5 & 0.10 & Quartzite \\
KV5 & 37 & 3 & 32 & 22 & - & - & 3 & 3 & 0.22 & Schist \\
KV4 & 52 & 3 & 28 & 11 & - & - & 2 & 4 & 0.18 & Micaceous quartzite \\
KV3 & 41 & 7 & 33 & 12 & - & 2 & 1 & 4 & 0.14 & Schist \\
KV13 & 29 & 4 & 37 & 23 & - & - & 3 & 4 & 0.19 & Schist \\
KV2 & 42 & 1 & 37 & 15 & - & - & 2 & 3 & 0.14 & Schist \\
KV1 & 41 & 3 & 31 & 18 & - & - & 1 & 6 & 0.19 & Schist \\
KV11 & 81 & 2 & 2 & 11 & - & - & - & 4 & 0.14 & Micaceous quartzite \\
KV12 & 74 & 1 & 14 & 9 & - & - & - & 2 & 0.16 & Micaceous quartzite \\
\hline
\end{tabular}

*Ipw (Petrographic weathering) $=\mathrm{WP} / 1-\mathrm{WP}$ and $\mathrm{WP}$ is $\%$ of weathered minerals.

minerals and unidentified minerals. The petrographic weathering index varies from 0.09 to 0.22 . It shows that the presences of weathered minerals grains are very low. The photomicrographs are shown in Figs 3-8.

The petrographic study shows that the tectosilicate minerals are greater than phylosilicate minerals in proportion on quartzite, meta-sandstone and meta-siltstone. Its proportion is slightly lower on psammitic schist. The mineral grains are indented and suture contact between the mineral grains shows the strong interlocking. The reactive silica are absent in all samples. Only the clay minerals illite and chlorite are present which are not more deleterious as they occur in less than $5 \%$.

\section{Alkali-silica reactivity}

Six samples having fine-grained size were selected after petrograhic study for further analysis using X-Ray difractometry. The result is shown in the Table 6 . Very fine quartz grains $(<15 \mu \mathrm{m})$ are present in metasiltstone (KV9), metasandstone (KV7) and psammitic schist (KV5, KV2). All the quartz grains are entirely low-T quartz. The fracture in quartz grains may be reactive (KV11, KV12). Some quartzfeldspar grains in other samples exhibit slight fractures. The deleterious clay minerals are not found in the samples. The diffractograms show only presence of illite, $1 \mathrm{M}$. The illite, $1 \mathrm{M}$ is a structural polytype in which sticking pattern is linear and unidirectional. It is not more harmful than smectite and kaolinite clay. The reactive silica and harmful clay minerals are therefore absent in the rock samples. Considering fracture and undulation in quartzite rock, the alkali-silica reactive potential is negligible.

\section{EVALUATION OF ROCKS FOR CONCRETE AGGREGATE}

The evaluation of rocks for concrete aggregate comparing with existing standard is summarised into Table 7. All the samples of rocks can be categorised into the following types based on field and laboratory analyses:

A. Metasandstone and calc-quartzite (KV6, KV7, KV8, KV10)

B. Micaceous quartzite (KV4, KV11, KV12)

C. Psammitic schist (KV5, KV3, KV2, KV1, KV13)

D. Metasiltstone (KV9)

The rock categories A, B and C are nearly similar with their physical, mechanical and chemical properties, and only the petrographic properties are quite difference. Only the category D (meta-siltstone, KV9) is quite difference mechanically, chemically and petrographically than others. The WAV, dry density and MBAV are average and meet the existing standard value for concrete aggregate in all samples. Alkali-silica reactive parameters are negligible and the presence of deleterious materials like clay (illite), chlorite and mica in almost all samples is little and other harmful swelling clay minerals (smectite) are absent. Therefore the rock samples have very low alkali-silica reactivity. 
Table 6: Alkali-silica reactive parameters present in the rock samples.

\begin{tabular}{|c|c|c|c|c|c|c|c|c|}
\hline $\begin{array}{l}\text { Sample } \\
\text { no. }\end{array}$ & Sampling site & $\begin{array}{l}\text { Rock type/ } \\
\text { Geological } \\
\text { Formation }\end{array}$ & Texture in thin-section & $\begin{array}{l}\text { Fine- } \\
\text { grained } \\
\text { quartz } \\
(<15 \mu \mathrm{m}) \\
\end{array}$ & $\begin{array}{l}\text { Quartz } \\
\text { type }\end{array}$ & Fracture & $\begin{array}{l}\text { Reactive } \\
\text { silica }\end{array}$ & $\begin{array}{l}\text { Clay } \\
\text { minerals }\end{array}$ \\
\hline Kv9* & $\begin{array}{l}\text { Up hillside of the } \\
\text { BP Highway, about } \\
3.5 \mathrm{~km} \text { from the } \\
\text { Dhulikhel }\end{array}$ & $\begin{array}{l}\text { Metasiltstone/ } \\
\text { Tistung } \\
\text { Formation }\end{array}$ & $\begin{array}{l}\text { The grains are moderately sorted, } \\
\text { submature and slightly oriented. The } \\
\text { slightly } 1 \text { set deformation is developed } \\
\text { (Fig. 3). }\end{array}$ & Present & $\begin{array}{l}\text { Low } \\
\text { quartz }\end{array}$ & Slight & Absent & 'Illite, IM \\
\hline Kv8 & $\begin{array}{l}\text { Up hillside of the } \\
\text { BP Highway, about } \\
5 \mathrm{~km} \text { from the } \\
\text { Dhulikhel }\end{array}$ & $\begin{array}{l}\text { Metasandstone } \\
\text { / Tistung } \\
\text { Formation }\end{array}$ & $\begin{array}{l}\text { Rounded to angular grains of quartz and } \\
\text { feldspars are moderately sorted, relict. } 1 \\
\text { set of slightly deformation is developed }\end{array}$ & Absent & $\begin{array}{l}\text { Low } \\
\text { quartz }\end{array}$ & Slight & Absent & - \\
\hline $\mathrm{Kv} 7^{*}$ & $\begin{array}{l}\text { BP Highway, about } \\
1 \mathrm{~km} \text { from the } \\
\text { Kavrebhanjyang } \\
\text { towards the } \\
\text { Dadagau. }\end{array}$ & $\begin{array}{l}\text { Metasandstone } \\
\text { / Tistung } \\
\text { Formation }\end{array}$ & $\begin{array}{l}\text { Fine grained moderately sorted, } \\
\text { equigranular quartz grains with } \\
\text { elongated chlorite that poorly defines } \\
\text { foliation; Some mud and silt matrix are } \\
\text { also visible; Preferred orientation of } \\
\text { muscovite and sericite (Fig. 4). }\end{array}$ & present & $\begin{array}{l}\text { Low } \\
\text { quartz }\end{array}$ & Slight & Absent & ${ }^{+}$Illite, $1 \mathrm{M}$ \\
\hline Kv6 & $\begin{array}{l}\text { Uphill side of BP } \\
\text { Highway, near the } \\
\text { Hanumanthan } \\
\text { school }\end{array}$ & $\begin{array}{l}\text { Metasandstone } \\
\text { / Tistung } \\
\text { Formation }\end{array}$ & $\begin{array}{l}\text { The grains are moderately sorted, } \\
\text { mature, point to suture contact. } \\
\text { Anhedral and subhedral grains are } \\
\text { slightly } 1 \text { set deformed. }\end{array}$ & Absent & $\begin{array}{l}\text { Low } \\
\text { quartz }\end{array}$ & Slight & Absent & - \\
\hline Kv10 & $\begin{array}{l}\text { Left bank of } \\
\text { Kubinde Khola } \\
\text { about } 1 \mathrm{~km} \text { upstream } \\
\text { from the confluence } \\
\text { of Kubinde Khola } \\
\text { and Dhital Khola }\end{array}$ & $\begin{array}{l}\text { Calc. quartzite/ } \\
\text { Marhu } \\
\text { Formation }\end{array}$ & $\begin{array}{l}\text { One set deformation, massive } \\
\text { polycrystalline, subhedral to anhedral, } \\
\text { angular grains of quartz are observed. }\end{array}$ & Absent & $\begin{array}{l}\text { Low } \\
\text { quartz }\end{array}$ & Slight & Absent & - \\
\hline Kv5* & $\begin{array}{l}\text { Uphill side of BP } \\
\text { Highway, near the } \\
\text { Dadagau village }\end{array}$ & $\begin{array}{l}\text { Psammitic } \\
\text { schist/Markhu } \\
\text { Formation }\end{array}$ & $\begin{array}{l}\text { Two set deformation, crenulated } \\
\text { structure, preferred orientation of mica } \\
\text { grains, mica fish, polycrystalline, } \\
\text { microlaminnae are present. }\end{array}$ & Present & $\begin{array}{l}\text { Low } \\
\text { quartz }\end{array}$ & Moderately & Absent & ${ }^{+}$Illite, $1 \mathrm{M}$ \\
\hline Kv4 & $\begin{array}{l}\text { BP Highway, about } \\
1 \mathrm{~km} \text { from the } \\
\text { Belldada towards } \\
\text { Dadagau }\end{array}$ & $\begin{array}{l}\text { Micaceous } \\
\text { quartzite/ } \\
\text { Markhu } \\
\text { Formation }\end{array}$ & $\begin{array}{l}\text { Quartz and feldspar grains are equant } \\
\text { and anhedral, homogenous fabric, } 1 \text { set } \\
\text { of deformation is developed indicated } \\
\text { by strong orientation of mica grains. }\end{array}$ & Absent & $\begin{array}{l}\text { Low } \\
\text { quartz }\end{array}$ & Slight & Absent & - \\
\hline $\mathrm{Kv} 3^{*}$ & $\begin{array}{l}\text { Up hillside of the } \\
\text { BP Highway, near } \\
\text { the Bella village }\end{array}$ & $\begin{array}{l}\text { Psammitic } \\
\text { schist/ Markhu } \\
\text { Formation }\end{array}$ & $\begin{array}{l}\text { One set deformation is clearly observed } \\
\text { by preferred orientation of the mica } \\
\text { grains (Fig. 5) }\end{array}$ & Absent & $\begin{array}{l}\text { Low } \\
\text { quartz }\end{array}$ & Slight & Absent & ${ }^{+}$Illite, $1 \mathrm{M}$ \\
\hline Kv13 & $\begin{array}{l}\text { Uphill side of } \\
\text { Arniko Highway, } \\
1 \mathrm{~km} \text { from Tinpiple } \\
\text { to Tamaghat at } \\
\text { stream channel }\end{array}$ & $\begin{array}{l}\text { Psammitic } \\
\text { schist/ } \\
\text { Kulekhani } \\
\text { Formation }\end{array}$ & $\begin{array}{l}\text { Recrystallized quartz and fenlspar } \\
\text { grains are subhedral to anhedral and } \\
\text { mica are niddle shaped. } 2 \text { set of strong } \\
\text { deformation is cleared. Suture and } \\
\text { indented contact among quartz grains } \\
\text { and deformation bands are prominent. }\end{array}$ & Absent & $\begin{array}{l}\text { Low } \\
\text { quartz }\end{array}$ & Moderately & Absent & - \\
\hline $\mathrm{Kv} 2 *$ & $\begin{array}{l}\text { Uphill side of BP } \\
\text { Highway, about } \\
2 \mathrm{~km} \text { from the } \\
\text { Golmithumka to } \\
\text { Bella village. }\end{array}$ & $\begin{array}{l}\text { Psammitic } \\
\text { schist/ } \\
\text { Kulekhani } \\
\text { Formation }\end{array}$ & $\begin{array}{l}\text { Two-set of foliation, edge of mica } \\
\text { grains are altered to cholorite. Cross cut } \\
\text { mica and heterogeneous distribution } \\
\text { with quartz. }\end{array}$ & Present & $\begin{array}{l}\text { Low } \\
\text { quartz }\end{array}$ & Slightly & Absent & ${ }^{+}$Illite, $1 \mathrm{M}$ \\
\hline $\mathrm{Kvl} 1^{*}$ & $\begin{array}{l}\text { Up hillside of the } \\
\text { BP Highway, about } \\
1 \mathrm{~km} \text { from the } \\
\text { Golmithumka to the } \\
\text { Bella village }\end{array}$ & $\begin{array}{l}\text { Psammitic } \\
\text { schist/ } \\
\text { Kulekhani } \\
\text { Formation }\end{array}$ & $\begin{array}{l}\text { Two-set deformation, crenulated } \\
\text { structures; Heterogeneous distribution } \\
\text { of recrystallized and deformed quartz } \\
\text { and mica; Presence of cross-cut of } \\
\text { biotite and muscovite (Fig. } 6 \text { ) }\end{array}$ & Absent & $\begin{array}{l}\text { Low } \\
\text { quartz }\end{array}$ & Moderately & Absent & 'Illite, 1M \\
\hline Kv11 & $\begin{array}{l}\text { Right bank of the } \\
\text { Okhar Khola; about } \\
100 \mathrm{~m} \text { upstream } \\
\text { from the suspension } \\
\text { bridge, way to } \\
\text { Baluwa }\end{array}$ & $\begin{array}{l}\text { Micaceous } \\
\text { quartzite/ } \\
\text { Chisapani } \\
\text { Quartzite }\end{array}$ & $\begin{array}{l}\text { One set of strong foliation seen by } \\
\text { preferred orientation of muscovite } \\
\text { grains (Fig. 7). }\end{array}$ & Absent & $\begin{array}{l}\text { Low } \\
\text { quartz }\end{array}$ & Highly & $\begin{array}{l}\mathrm{V} \text {. low } \\
\text { reactive }\end{array}$ & - \\
\hline Kv12 & $\begin{array}{l}\text { Right bank of the } \\
\text { Bhotekate Khola, } \\
\text { below the Charuwa } \\
\text { village }\end{array}$ & $\begin{array}{l}\text { Macaceous } \\
\text { quartzite/ } \\
\text { Kalitar } \\
\text { Formation } \\
\end{array}$ & $\begin{array}{l}\text { One set of strong foliation defined by } \\
\text { mica minerals. Quartz grains are } \\
\text { recrystallized and deformational } \\
\text { laminae of mica are frequent (Fig. } 8 \text { ). }\end{array}$ & Absent & $\begin{array}{l}\text { Low } \\
\text { quartz }\end{array}$ & Highly & $\begin{array}{l}\text { V. low } \\
\text { reactive }\end{array}$ & - \\
\hline
\end{tabular}

${ }^{*} \mathrm{XRD}$ analysis, ${ }^{+} \mathrm{Illite}, 1 \mathrm{M}$ is a structural polytype in which stacking pattern is linear and unidirectional. 


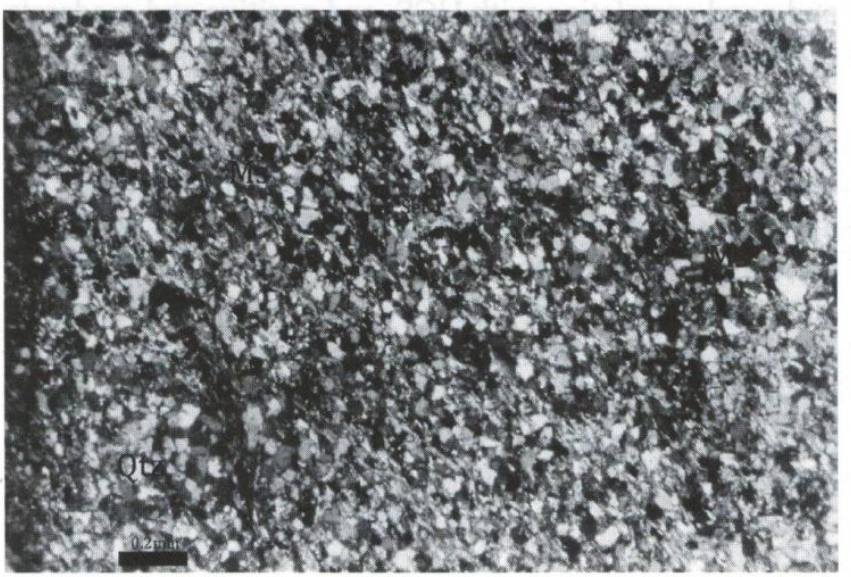

Fig. 3: Photomicrograph of metasiltstone showing the equigranular quartz grains and microlaminae (Sample no. KV9). Qtz=quartz, ser=sericite, Ms=muscovite.

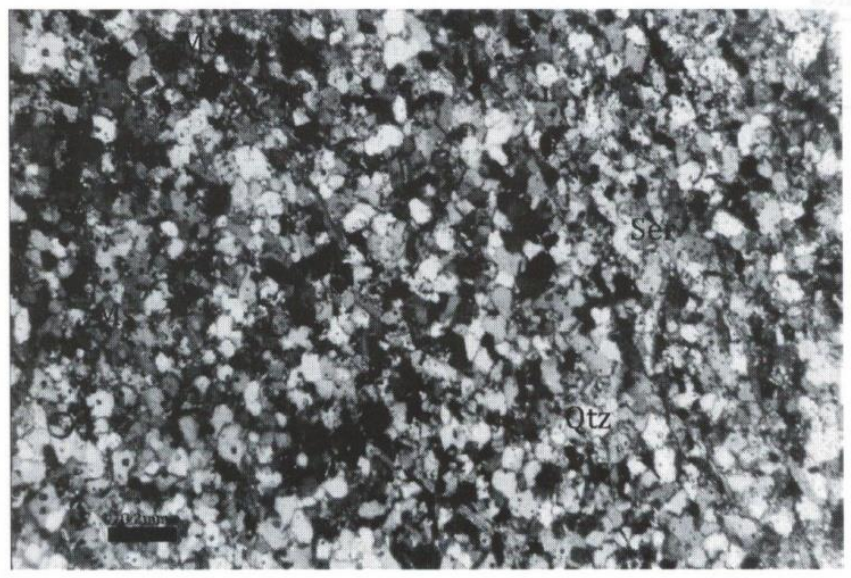

Fig. 4: Photomicrograph of metasandstone showing the equigranular quartz grains and microlaminae (Sample no. KV7). Qtz=quartz, ser=sericite, Ms=muscovite.

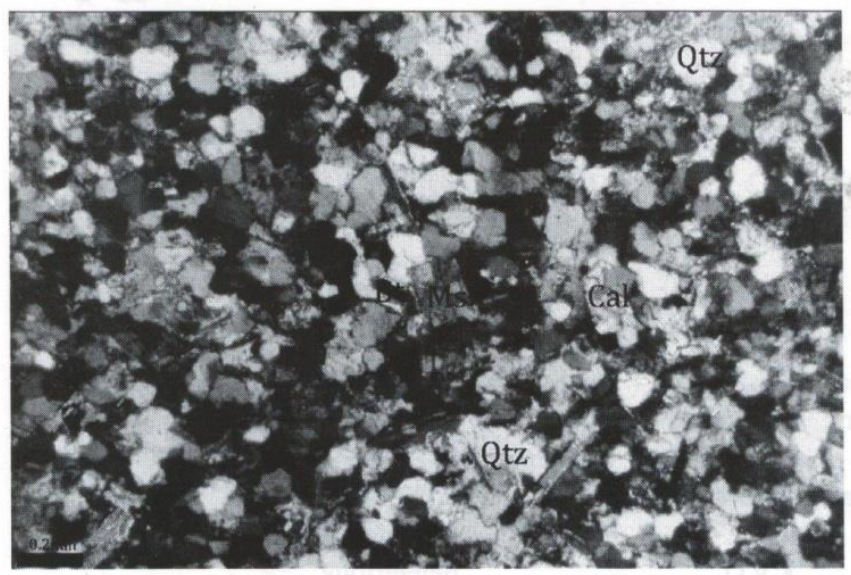

Fig. 5: Photomicrograph of psammitic schist showing the granoblastic texture, anhedral predominant quartz and slightly oriented mica (Sample no. KV3). Qtz=quartz, $\mathrm{Cal}=$ calcite, $\mathrm{Bt}=$ biotite, $\mathrm{Ms}=$ muscovite.

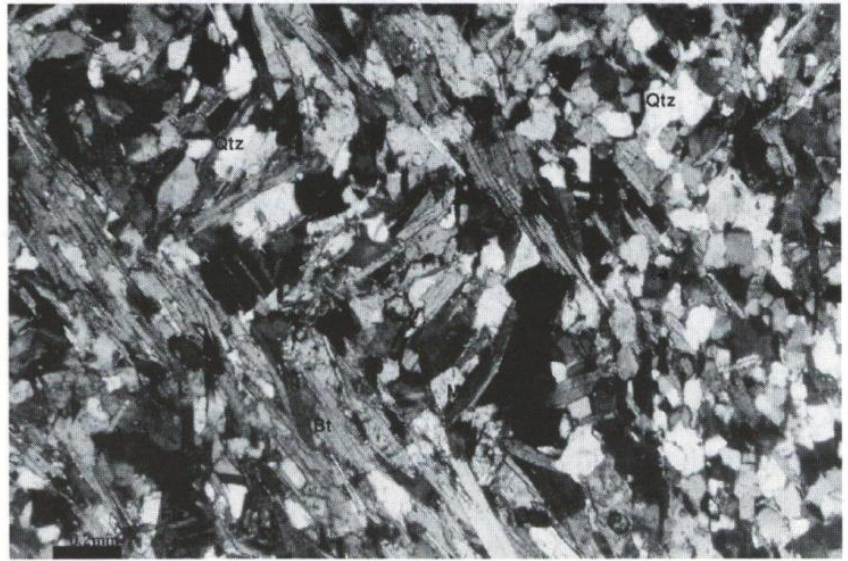

Fig. 6: Photomicrograph showing the fine grained recrystallized quartz, orientation of mica and crenulation cleavage (Sample no. KV1). Qtz=quartz, Fls=feldspar, Bt=biotite, $M s=$ muscovite.

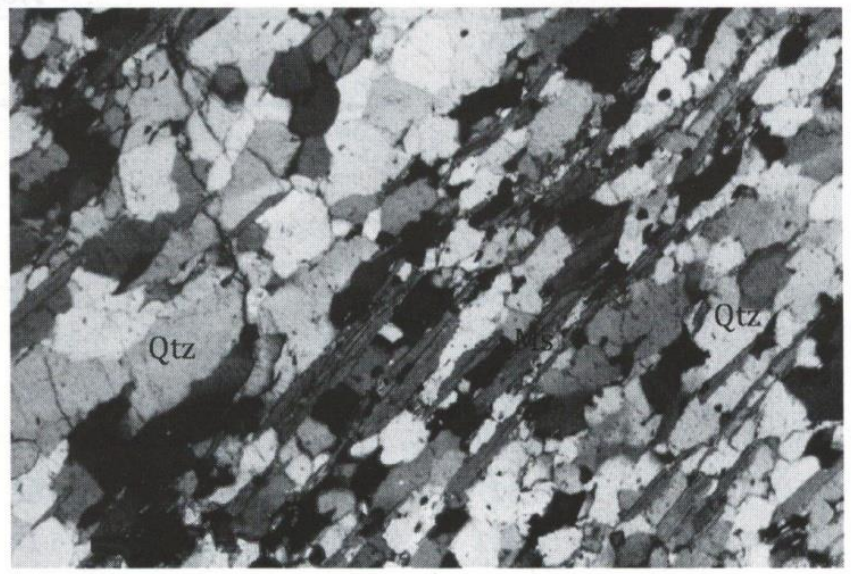

Fig. 7: Photomicrograph of quartzite showing the coarse grained, fractured, undulose extinction, on quartz and preferred orientation of muscovite (Sample no. KV11). Qtz=quartz, Ms=muscovite.

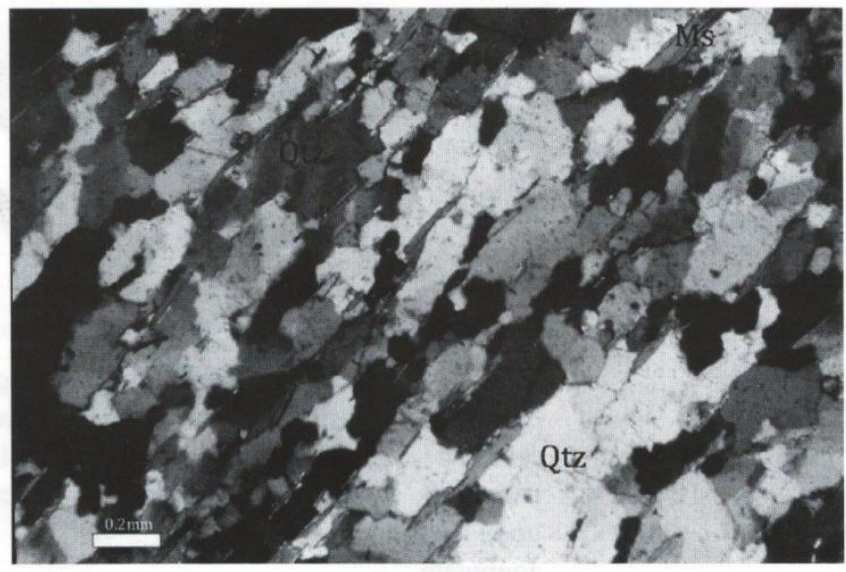

Fig. 8: Photomicrograph showing the undulose extinction, suture contact, fractured and coarsely crystalline quartz and orientation of mica grains (Sample no. KV12). Qtz=quartz, Ms=muscovite. 


\section{Correlations among physical, mechanical and}

\section{petrographical parameters}

When all the thirteen samples were correlated for each of individual parameters, only the relationships between ACV and AIV, UCS and ACV, Dry density and ACV and Dry Density and AIV were found to be of moderate degree of correlation. Therefore, attempt has been made to correlate and regress among the parameters for two distinct rock types: (a) quartzite/metasandstone/metasiltstone and (b) schist (Figs. 9 and 10). Considering the correlations in quartzite/metasandstone/metasiltstone, $\mathrm{ACV}$ has negative and good correlation with UCS, and positive and moderate correlation with AIV and dry density (Fig. 9). AIV is better explained by ACV compared to the other parameters, suggesting that whenever the aggregate crushing value increases in quartzite/meta-sandstone/meta-siltstone, the aggregate impact value also tends to increase. In schist, there are good and negative correlations between UCS and ACV and between dry density and ACV. ACV explains moderately the AIV and shows positive correlation. The mineralogical components such as quartz and feldspars (Qtz+Fls) also explain SSSV with good positive correlation (Fig. 10).

Table 7: Rock properties of the study samples compared with existing standard values and evaluation for concrete aggregate.

\begin{tabular}{|c|c|c|c|c|c|c|c|c|c|}
\hline \multirow{2}{*}{$\begin{array}{l}\text { Sample } \\
\text { no. }\end{array}$} & & \multicolumn{7}{|c|}{ Properties } & \multirow[b]{2}{*}{ Evaluation } \\
\hline & & $\begin{array}{l}\text { WAV } \\
(\%)\end{array}$ & $\begin{array}{l}\text { DD } \\
(\%) \\
\end{array}$ & $\begin{array}{l}\mathrm{ACV} \\
(\%) \\
\end{array}$ & $\begin{array}{l}\text { AIV } \\
(\%)\end{array}$ & $\begin{array}{l}\text { SSSV } \\
(\%)\end{array}$ & $\begin{array}{l}\text { MBAV } \\
(\%)\end{array}$ & $\begin{array}{l}\text { ASR/ } \\
\text { deleterious }\end{array}$ & \\
\hline KV9 & $\mathrm{D}$ & 0.739 & 2.591 & 35.4 & 20.76 & 16.66 & 0.83 & No/little & $\begin{array}{l}\text { Chemically } \\
\text { unsound, } \\
\text { mechanically } \\
\text { satisfactory }\end{array}$ \\
\hline KV8 & A & 0.450 & 2.658 & 24.83 & 17.12 & 7.93 & 0.67 & No & Good for aggregate \\
\hline KV7 & A & 0.586 & 2.525 & 22.73 & 15.01 & 10.71 & 0.50 & No/little & Good for aggregate \\
\hline KV6 & A & 0.902 & 2.308 & 21 & 12.49 & 10.44 & 0.67 & No & Good for aggregate \\
\hline KV10 & A & 1.189 & 2.483 & 21.4 & 15.55 & 13.28 & 0.67 & No & Chemically fair \\
\hline KV5 & $\mathrm{C}$ & 0.327 & 2.743 & 19.56 & 11.02 & 10.26 & 0.50 & No/little & Good for aggregate \\
\hline KV4 & B & 0.302 & 2.673 & 22 & 16.12 & 9.91 & 0.67 & No & Good for aggregate \\
\hline KV3 & $\mathrm{C}$ & 2.392 & 2.359 & 30.5 & 23.67 & 11.02 & 0.50 & No/little & $\begin{array}{l}\text { Mechanically } \\
\text { satisfactory }\end{array}$ \\
\hline KV13 & $\mathrm{C}$ & 0.401 & 2.735 & 23.16 & 23.84 & 5.95 & 0.50 & No & Good for aggregate \\
\hline $\mathrm{KV} 2$ & $\mathrm{C}$ & 0.691 & 2.645 & 23 & 23.31 & 9.97 & 0.67 & No/illite & Good for aggregate \\
\hline KV1 & $\mathrm{C}$ & 0.488 & 2.644 & 22.16 & 19.29 & 9.97 & 0.67 & No/little & Good for aggregate \\
\hline KV11 & B & 0.405 & 2.569 & 24.66 & 22.43 & 12.08 & 0.50 & No & Chemically fair \\
\hline KV12 & B & 0.357 & 2.599 & 25.66 & 22.64 & 12.55 & 0.50 & No & Chemically fair \\
\hline $\begin{array}{l}\text { Existing } \\
\text { standards }\end{array}$ & $\begin{array}{l}\text { ASTM } \\
\text { BS }\end{array}$ & $<1$ & $2-3$ & $<30$ & $<30$ & $<12$ & $<1 \%$ & & \\
\hline & NS & $<4$ & 2.622 & $<45$ & $<45$ & $<12$ & & $<5$ & \\
\hline Remarks & & $\begin{array}{l}\text { Low } \\
\text { effective } \\
\text { porosity } \\
\text { and act as } \\
\text { good for } \\
\text { aggregate }\end{array}$ & $\begin{array}{l}\text { Average } \\
\text { density } \\
\text { for } \\
\text { aggregate }\end{array}$ & $\begin{array}{l}\text { Sound } \\
\text { for } \\
\text { concrete } \\
\text { aggregate }\end{array}$ & $\begin{array}{l}\text { Strong and } \\
\text { satisfactory } \\
\text { to resist } \\
\text { impact load }\end{array}$ & $\begin{array}{l}\text { Resist to } \\
\text { chemical } \\
\text { weathering } \\
\text { except } \\
\text { KV9, } \\
\text { KV11, } \\
\text { KV12, } \\
\text { KV10 }\end{array}$ & $\begin{array}{l}\text { Negligible } \\
\text { amount of } \\
\text { swelling } \\
\text { clay }\end{array}$ & $\begin{array}{l}\text { Absence of } \\
\text { alkali-silica } \\
\text { reactivity } \\
\text { and little } \\
\text { presence of } \\
\text { deleterious } \\
\text { materials }\end{array}$ & \\
\hline
\end{tabular}

$\mathrm{A}, \mathrm{B}, \mathrm{C}$ and $\mathrm{D}$ are rock categories 
Physical, mechanical and petrographic properties of Lesser Himalayan rocks
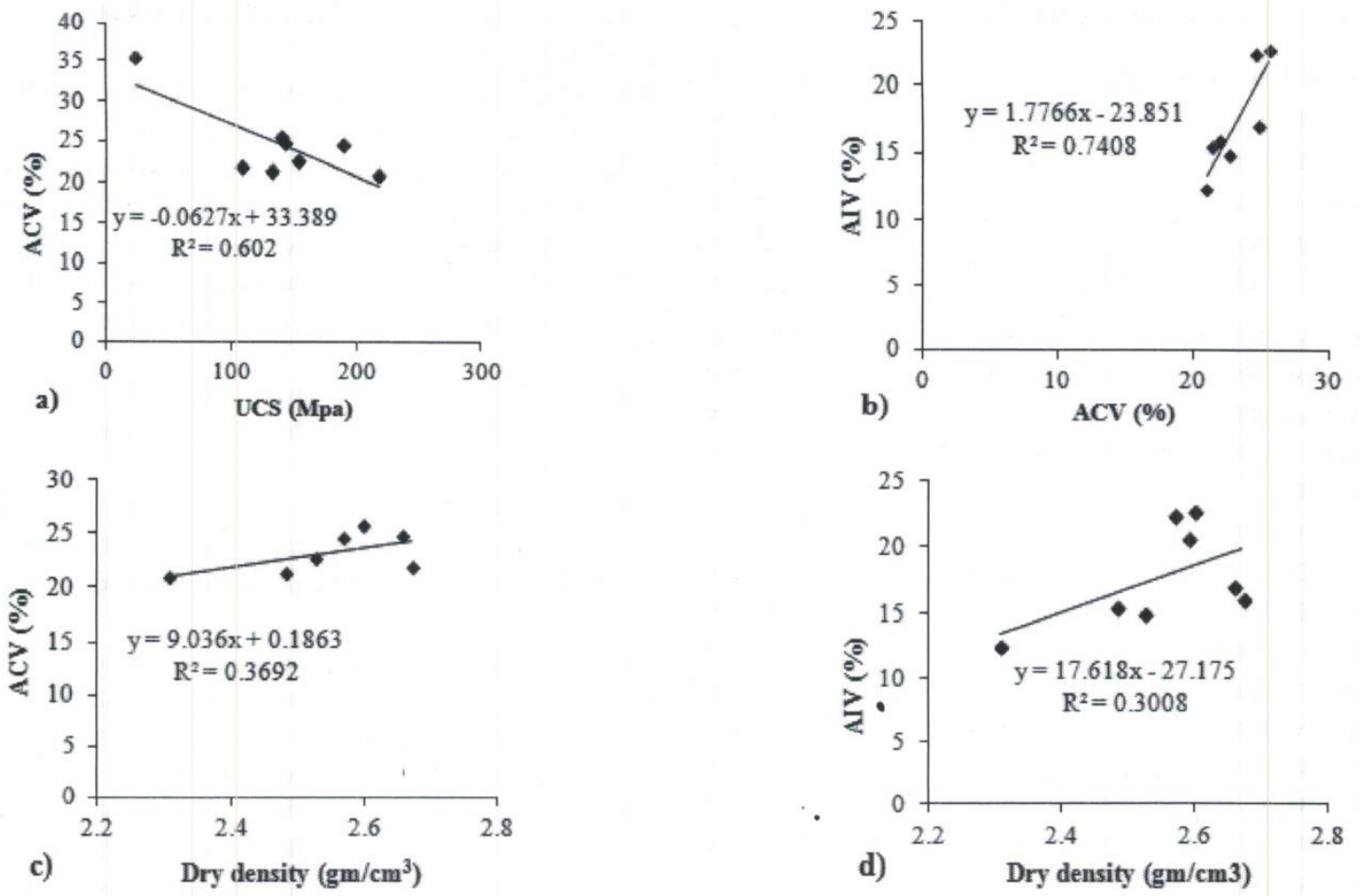

Fig. 9: Relationship between different parameters in metasandstone/metasiltstone/quartzite. a) UCS and ACV b) ACV and AIV c) dry density and ACV and d) dry density and AIV.
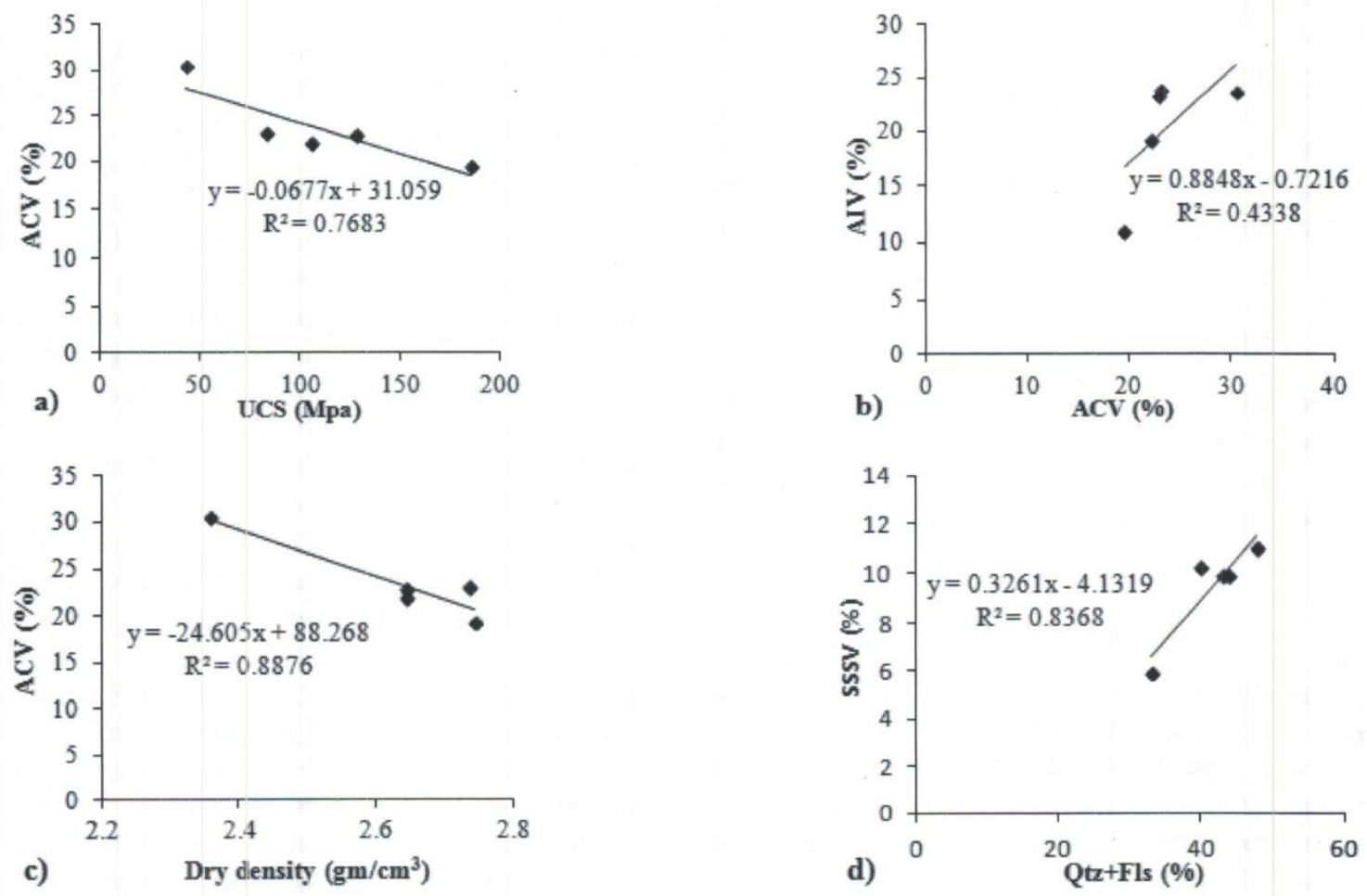

Fig. 10: Relationship between different parameters in psammitic schist. a) UCS and ACV b) ACV and AIV, c) dry density and ACV and d) quartz+feldspar and SSSV. 


\section{CONCLUSIONS}

1. The Kavre area comprises the Lesser Himalayan rocks, which consist mainly of three to four major joint sets, the rock mass is nearly fresh, indurated and strong enough showing that the aggregates have a good stiffness for using as concrete aggregate. The rock masses are classified into fair to good rock class according to rock mass rating system.

2. The Lesser Himalayan rocks from the Kavre area meet the ASTM standard and Nepal Standard and are acceptable for concrete aggregate. However, except for metasiltstone which cannot be used in pavement as it shows high ACV, SSSV and clay. The psammitic schists are less prioritized for the aggregate due to high mica content. The best selection among the rock type for the concrete aggregate is metasandstones of the Tistung Formation and quartzite of the Markhu Formation. Second selection is quartzites of the Kalitar Formation, Chisapani Quartzite and Markhu Formation. Such rock types have been widely distributed around the peripheral regions of the Kavre area along the Arniko Highway and BP Highway. Therefore, these rocks can be the better source for concrete aggregate which can be used on increasing infrastructure development.

3. ACV of quartzite/metasandstone/metasiltstone has positive and moderate correlation with AIV and dry density, but negative and good correlation with UCS. AIV is better explained by ACV compared to the other parameters. In case of schists, there are good and negative correlations between ACV and UCS, and between ACV and dry density. ACV explains moderately the AIV and shows positive correlation. The mineralogical components such as quartz and feldspars (Qtz+Fls) also explain SSSV with good positive correlation.

\section{ACKNOWLEDGEMENTS}

Authors are thankful to Central Department of Geology, Tribhuvan University, East Management and Engineering services Pvt. Ltd., and Pulchowk Engineering College for providing laboratory facilities.

\section{REFERENCES}

ASTM International, 1989, Specific gravity and absorption of the Aggregate. C127-88 and C128-88.

ASTM International, 1994, Standard Specification for Transportation Materials and Methods for sampling, Washington D.C.

ASTM International, 2003, Standard guide for Petrographic examination of aggregate for concrete. C295-03. pp. 1-8 (www.astm.org).

ASTM International, 2005, Standard test method for Soundness of Aggregates by use of sodium sulphate or magnesium sulphate. C88-05.
Bieniawski, Z. T., 1976, Rock Mass Classification in Engineering, pp. 97-106.

Bieniawski, Z.T., 1989, Engineering rock mass classifications. John Wiley \& Sons, New York, 251p.

Dhakal, G. P., Kodma, J. and Goto, J., 2006, Freezing-Thawing effect and slake durability of some rocks from cold regions of Nepal and Japan. Nepal Geological Society, v. 33, pp. 45-54.

DOR, 2001, Standard Specification for Road and Bridge Works, Report of Ministry of Physical Planning and Works, pp. 6001200.

GSL, Geological Society London, 1977, The description of rock masses for Engineering Purpose. Engineering Group working party report. v. 10, pp. 355-388.

Hills, J. F. and Pettifer, G. S., 1985, The clay mineral content of various rock types compared with the methylene blue value. Journal of Chemical Technology and Biotechnology, v. 35(A4), pp. $168-180$.

ISRM, 1979, Suggested methods for determining water content, porosity, density, water absorption and related properties and swelling and slake-durability index properties. Intl. soc. Rock, mech. min. sci. and Geomech. Abstr., v.16, pp. 141-156.

Khanal, S. and Tamrakar, N. K., 2009, Evaluation and quality of crushed- limestone and siltsone for road aggregates, Bulletin of Department of Geology, Tribhuvan University, v.12, pp. 29-42.

Larsen, G. Federiksen, J. Villumsen, A. Federicia, J. Gravesen, P. Foged, N., Knudsen, B. and Baumann, J., 1995, A Guide to Engineering Geological soil description. Denish Geottecnical Society, Bulletin, 1.

Maharjan, D. K. and Tamrakar, N. K., 2003, Quality of Siltstones for Concrete Aggregates from Nallu Khola Area, Kathmandu, Nepal Geological Society, v. 30, pp. 167-176.

Nepal Standard, 1994, Specification for Aggregates, (NS: 297-2050, U.D.C. No. 620, 113), His Majesty of Government, Ministry of Industry, Commerce and Supply., Nepal Bureau of Standard Measurement. Balaju, Kathmandu.

Paudel, P. N. and Tamrakar, N. K., 2012, Geology and rockmass condition of Dhulikhel-Panchkhal area, Kavre District, Central Nepal, Lesser Himalaya, Bulletin of Department of Geology, Tribhuvan University, v. 15, pp. 1-14.

Stöcklin, J., 1980, Geology of Nepal and its regional Frame. Journal of the Geological Society of London, v. 137, pp. 1-34.

Stöcklin, J. and Bhattarai, K. D., 1977, Geology of the Kathmandu area and Central Mahabharat Range, Nepal Himalaya. Report of Department of Mines and Geology/ UNDP (unpublished), $86 \mathrm{p}$.

Tamrakar, N. K. and Paudel, L. P., 2011, Petrographic analysis of carbonate rocks from alkali-aggregate reactivity. Bulletin of Department of Geology, Tribhuvan University, v. 14, pp. 15-20.

Tamrakar, N. K., Paudayal, K. N. and Dhital, M. R. 1997, Geology of the Jhiku Khola Watershed area (unpublished report submitted to Mountain Risk Engineering unit, Tribhuvan University).

Tamrakar, N. K., Yokota, S. and Shrestha, S. D., 2002, Physical and Geomechanical properties of the Siwalik Sandstones, Amlekhgunj-Suparitar Area, Cenetral Nepal Himalaya, Journal of Nepal Geological Society, v. 26, pp. 59-71. 